SIR-The report (Nature 321, 89; 1985) by Tony Thulborn on the evolution controversy as it affects secondary biology teaching in Queensland is fundamentally in error. The chief error is the statement that the teaching of creationism "is officially included in the school science curriculum". The truth is that creationism was deleted from the Queensland science syllabus in 1983. A teacher wishing to include creationism, or any other deviation from the syllabus, in the high-school biology curriculum must receive approval for the work programme from the Board of Secondary School Studies acting on recommendations by the District and State Review Panels. In other words, not only is creationism not included in the official science curriculum but its inclusion as a local variation must satisfy two screenings before receiving the board's approval.

Thulborn's statement that Queensland science teachers "are now obliged to present the conflicting arguments for creation and catastrophism" thus bears no relation to the prescribed curriculum. His statement is a highly tendentious interpretation of remarks by the Minister for Education, Mr Lin Powell, concerning "balance" in the teaching of evolution. $\mathrm{Mr}$ Powell has spoken for himself in the letters column of this journal (Nature 324, 204 ; 1986).

Building on this fundamental error, Thulborn describes a school-room crisis. He reports the formation of the Australian Association for the Protection of Evolution at a rally called to combat the furious onslaught of creationism. The alarming threat is heightened by reporting the decision taken by the association to assemble "survival kits" for teachers facing the creationist scourge. This crisis exists entirely in the imaginations of Thulborn and a handful of his associates. The survival kits have never been issued, no doubt for the good reason that they are irrelevant to the life of science instructors.

School of Humanities,

Griffith University,

Brisbane,

Queensland 4111,

Australia

Thulborn REPLIES-My report about creationism in Queensland was neither erroneous nor fanciful.

An instruction to include creationism in the science syllabus was first issued to Queensland school principals on 30 November 1981 by the then Minister for Education, Mr William Gunn. In November 1983, as Hiram Caton observes, the Board of Secondary School Studies released a draft syllabus (biology) which made no mention of creation. Neverthe- less, the present Minister for Education, Mr Lin Powell, insists that teachers should still heed the 1981 instruction. In 1984 he tabled that instruction (sic) in the Queensland State Parliament, in response to questions about the teaching of creationism in state schools (Hansard, 10 April 1984). One member of parliament noted that the minister "failed to confirm or deny if biology teachers were being forced to teach creationism" (Sydney Morning Herald, 12 May 1984). In 1985, Powell said that "there would be no change in the secondary science syllabus, and the 1981 recommendations still stood" (Brisbane Courier-Mail, 30 April 1985). And in a published letter he has stated that the 1981 directive was "to ensure that students are exposed to both creationism and evoution" (Brisbane Courier-Mail, 13 May 1985). It is therefore legitimate to conclude that Powell, in his official capacity as Queensland's Minister for Education, has instructed teachers to include creationism in the school science syllabus.

Caton describes elaborate procedures to monitor the content of the science syllabus. Those safeguards certainly exist, though they are sometimes circumvented or ignored. In fact they have been most blatantly abused by the minister himself: Powell's instructions about "balanced" presentation have been addressed directly to school principals, thus side-stepping the approved procedures whereby the science syllabus is constructed and maintained by the Board of Secondary School Studies. In any case, it is obvious that existing safeguards do not exclude creationism from science classes.

In May 1984, an informed source in the Queensland Education Department revealed that only half of the science curriculum was prescribed by the department. "The remainder is determined by each school, which has to submit a school work program to the Board of Secondary School Studies. That board has been partial to proposals to teach creationism" (Sydney Morning Herald 12 May 1984).

In the same newspaper article, a senior science teacher commented that "creationists now have an open hand to teach it [creationism] with the official sanction of the Queensland Government and many are doing just that. The obvious next step is for creationism to become compulsory teaching in Queensland schools, and we are perilously close to that now." In addition, a lecturer at the Brisbane College of Advanced Education confirmed that several schools were known to teach creationism, identifying one of them by name. Last year, one science teacher recounted his experience when he refused to introduce creationism in his biology classes: those classes were promptly handed over to a teacher trained in Home Economics (The Skeptic, November 1986, p.20). He also mentioned that one of his colleagues was being harassed because his teaching of ancient history conflicted with literal interpretation of the Bible. In short, a few teachers are fundamentalists who will teach creationism regardless of any official prohibitions; and other teachers have been encouraged, pressured or plainly instructed to bring creationism into their science classes.

On 10 July 1986, the executive committee of the Australian Academy of Science issued a statement condemning the teaching of creationism in school science courses. That statement makes particular reference to Queensland. Similar action has been taken, or is being considered, by other scientific, educational and religious bodies throughout Australia. Recently the Continuing Education Unit at Queensland University offered a short course specifically designed to help local schoolteachers to deal with evolution and creationism in their classes; more than 70 people enrolled.

The publication of a popular book titled Creationism, An Australian Perspective (edited by M. Bridgstock and K. Smith, Australian Skeptics, Melbourne) has been resoundingly successful: the first two editions were sold out in a matter of weeks, and the third has just been released. The book is proving particularly useful to the many teachers who are understandably perplexed by the whole issue. I am pleased to report that the Australian Association for the Protection of Evolution made useful contributions to these and several other ventures.

TONY THULBORN

Department of Zoology,

University of Queensland,

St Lucia,

Queensland 4067,

Australia

\section{Research assistants}

SIR-I note that you continue to publish letters on the "plight of British postdocs". I write now to suggest a comparatively simple step that would at least remove one irritation. I refer to the use of the word "assistant". While it is not unreasonable to advertise for "research assistants" at the grade of postgraduate, it seems both insulting and inaccurate to refer to "postdoctoral research assistants". Surely those advertising are seeking people who should contribute originality to the solution to a problem and are not mere assistants.

We suggest that postdoctorals should in future be referred to as research scientists, research biochemists or research fellows.

P.N. CAMPBELL

Department of Biochemistry,

Middlesex Hospital Medical School,

London WIP 6DB, UK 